\title{
The Analyses of Albanian Budget Expenditure
}

\author{
Doc. Ph. D. Dorjana Nano \\ Lecturer University "Eqrem Cabej" \\ Email: nano.dori@yahoo.com \\ Ph. D Cand. Eduina GUGA \\ Manager at "Guga Electronics" \\ Email: eduina.guga@hotmail.com
}

\begin{abstract}
Public expenditure efficiency has been an issue of concern for many researchers. Studies have shown that public budget of the developed and developing economies is not optimally allocated and managed. Anyway, discrepancies are found between both economies. This paper aims to investigate and critical analyze the allocation of public expenditure in the Republic of Albania. In addition, it provides some relevant comparison of the performance indicators among Albania, regional countries and OECD states. Data provided by the Ministry of Finance and Open Access Data are evaluated by considering the functional classification of the budget expenditure. Results of this study suggest that Albania spends more on social protection and social security, and less on education and health compared with the average of the EU countries and OECD countries. In addition, inefficiency of the public sector is discovered. This research recommends the necessity in the improvement of input allocation by using 70 percent less resources to achieve the same amount of public output and consequently contributing positively on fiscal consolidation.
\end{abstract}

Keywords: analyses, albanian, budget, expenditure

\section{Introduction}

Albania is experiencing the transformation phase for more than 23 years. The importance of the public and private sectors on the economic development has being augmented significantly. Although the increasing role of the private sector on allocation of resources and GDP contribution, it is found evidence that public sector plays a major part on money distribution. According to Curristine (2009) a significant portion of monetary values is distributed and redistributed through the public sector, which in different countries, ranges from $25-60 \%$ of the GDP.

Government plays a major role on the development and progress of the country since it by has the legal right and financial tools for attracting a substantial portion of the income from the private sector through the taxation system. It is also its responsibility for the public expenditure efficiency, which consists on the use of resources so as to maximize the production of public goods and services. According to Verhoeven et al. , (2007) , an economic system is said to be more efficient than another (in relative terms), if it can provide more public goods and services for society without using more resources.

There are a lot of reasons that emerge the importance of analyzing the public expenditures conducted by the government. Firstly, the public sector economic activities, carried out by the government, have a specific character and do not submit to the same rules compared to those of the private sector function. The main principle governing private sector economic activities is "voluntary exchange", which according to Adam Smith (1776) makes it possible for all to win. Since the activity of government is not based on voluntary exchange of services provided, then the analysis and transparency of costs conducted by the government is not only a necessity, but also the only way for the public to understand what the activities and services offered and provided by the government are. Secondly, the analysis of government expenditure is important to be conducted in order to give a clear view on how these expenses are financed. Public expenditures could theoretically be financed through taxes, loan and by printing of new money. All three of these ways have different impacts on the 
economy of a country, and that is the reason why this analysis is necessary. Thirdly, analysis of public expenditure is a necessity to identify the cost of the services provided by the government. Cost analysis, i. e. of government efficiency is particularly necessary during the process of decentralization, where, given the principle of subsidiary, the efficiency of the governing levels is a basic criterion to decide on the distribution of functions between local and central government. Finally, expenditure control is an important process for controlling bureaucracy. Analysis of the public sector in different countries has proved that in a situation where public control lacks, over public finances, then the growth of the budget expenditure is encouraged, in order to keep the administration, reducing at the same time the quantity and quality of public services derived directly from the public (Dhori Kule, Olta Milov, 2008).

This research aims to analyze Albania's Republic Budget for the period of 2006-2013 in order to highlight and evident its main focus among different functions. The main objectives of the study are:

- to identify the importance of the public expenditure analyses on economic development of a country;

- $\quad$ to review and analyze the existing literature on the efficiency of public expenditures;

- $\quad$ to conduct a detailed analyses of the Albanian public expenditures based on the period $2006-2013$ and to make relevant comparison among Albania, countries in the region and OECD states.

- $\quad$ to draw some conclusions and policy implications with regard to improve public expenditure effectiveness.

\section{Literature Review}

Efficiency of public spending has been studied extensively in recent years, particularly in relation to general expenditure, education and health. Efficiency is the relationship between resources used and the maximum possible goods and services produced by this amount of resources. Clements (2002) noted that about 25 percent of expenditures for education are abused in EU countries, while best practices are observed in OECD countries. Alfonso et al. , (2005) conducted a research on public expenditure efficiency of the 23 member countries of the OECD (Organization for Economic Co-operation and Development). They constructed seven semi- public performance indicators. Authors discovered inefficiency of the public expenditure and argued that these countries could have increased the results by 11.6 percent using the same resources. However, it is pointed out that inefficiency is closely as well related with other factors beyond government control, such as the average economic level of the families and level of parental education. In 2010, this study is enriched by extending the analysis considering the new member states of the European Union (EU). Alfonso et al. , found that countries with small public sector (public expenses less than 40 percent of GDP) tend to be more efficient. Results demonstrated that efficiency varies substantially among EU member states, which in turn means that there is a great potential for savings. The results of these studies are limited regarding the tools used to measure the performance and the influence of exogenous factors beyond the control of public authorities.

Verhoeven et al. , (2007) evaluated the efficiency of expenditure on health and education in the G7 countries, and suggested measures to be undertaken in order to increase the efficiency, including careful planning and personnel management, reallocation of costs to outputs cost-effective, and implementation and enforcement of the regulatory framework.

Spinks and Hollingsworth (2009) utilized the evaluation techniques without parameters to determine the relative technical efficiency of health expenditure among the OECD member countries. They used an output-oriented Data Envelopment Analysis (DEA) to measure the technical efficiency of the health systems using the latest data available on infant death and life expectancy as health outcomes. Their results showed that technical efficiency varies across these health systems and this translates into potential savings of resources. The average efficiency scores for all heath systems were 0.98 for life expectancy at birth and only 0.821 for infant mortality. More than half of the health systems in the sample were technically inefficient in 2009 for both outputs. They found that $30 \%$ of national health systems were technically efficient for both outputs. 
Taking advantage of the availability of new indicators, Sopek (2011) has undertaken a research on analyzing the efficiency of public spending on education in Croatia using the PISA scores ${ }^{1}$. Author suggests that Croatia has still room for improving the efficiency of its system.

Despite the large body of foreign literature studied the efficiency of public expenditure, there is still a lack analyzing this topic recently in Albania. Centre for Research and Development (CRD) conducted a research in Albania aimed to analyze the performance of Albanian public expenditure for the years 1993-2003, according to the economic and functional classification ${ }^{2}$. Results of this study demonstrated a discrepancy between economic development priorities and planned expenditures for priority areas such as education and health. Health was found to be the sector with the largest difference for available funds, compared to other developed countries. In addition, some deficiencies in the costs for central administration budget line were noticed in the budgetary planning in 2005. The planned expenditures for central administration were resulted to be about 30 percent less than the costs actually incurred during 2003, which could create anomalies in the functioning of central institutions activities during the budget implementation. Furthermore, some deviations were discovered among facts and plans, especially in the economic costs and unemployment assistance for the years 1999-2002 (up to $101 \%$ ), housing for 2000 (642\%), order and security for the years 1999 and 2000 (up 113 percent) etc. These deviations are explained by a periodic lack Parliament supervision of the expenditures and as well as the low capacity for managing the state budget by the respective ministries. Finally, compared to the years 1999-2001, it was observed an improvement of the planning and monitoring of implementation of the state's budget for 2002 and 2003.

\section{Methodology}

This research assesses the efficiency of the budget expenditures in Albania for the period 2006 - 2013. Efficiency is measured by making use of indexes and performance indicators provided by the Ministry of Finance and Open Data Access. The analysis is based on the functional classification of public expenditure which intends to show the direction where public funds are spent. This classification includes "code" and "function", as follows:
01. General Public Services
02. Protection
03. Order and Public Safety
04. Education
05. Health
06. Insurance and Social Assistance
07. Recreation, Culture \& Religious Affairs
08. Energy
09. Agriculture, Forestry, Fishing \& Hunting
10. Mineral Resources
11. Transport and Communications

\footnotetext{
2 Economic classification of budget expenditures serves to indicate the purpose of Use of revenues, as such, they do not show where they are spent, but the economic direction of the expenditure budget, is on seven classes: Current Expenditures, Staff, Interests, Operating Expenses \& Maintenance, Subsidies, Social Insurance Costs, Local Government Expenditures, Other expenses, Capital Expenditures (Law no. 9936, dated 26.06.2008 "On budget system managemen")
} 


\section{Other Commercial Services}

13. Other expenses

Comparative technique and ground theory are utilized. The comparative study is useful in order to compare the indexes and the priorities sectors among Albania, countries in the region and OECD states. In addition, this comparison will be valuable to examine any lack or deficiency in the Albanian budget allocation and management.

\section{Data Analyses of the State Budget}

The analysis of expenses by function is very important because in this way can be explained which were the sectors where that the budget funds are directed. This is ultimately because the public is primarily interested to know where and in what sectors budgetary funds are spent. Likewise, the expenditure analysis shows where and how the funds are spent and how the political priorities are established to support specific sectors and with the achievement of these priorities. The expenditure analysis by function, through indicators expressed as a ratio to GDP, also serves to determine fairly and precisely the objectives for the coming years. This is because accurate prognosis cannot be conducted if the history of budget expenditures in prior periods is not available. Finally, the analysis of expenses by function is important to compare the level of expenses incurred in Albania with that of the developing countries or with equal or higher development.

\section{Budgetary expenditures of Albania compared with regional countries}

The line chart below provides information about the budget expenditure in percentage of GDP for Albania and region countries. As it can be seen from the Figure 1, Albania has the lowest expenditures to GDP in the region. Meanwhile, ranked in first place is Greece (50.4\%), followed by Bosnia and Herzegovina (50\%), Montenegro (47\%), Serbia (44\%), Croatia (42\%), Turkey (37\%), Macedonia (33\%) and Kosovo (31\%).

Figure 1: Budget Expenditure of the Region in \% of GDP, Source: ODA, 2014

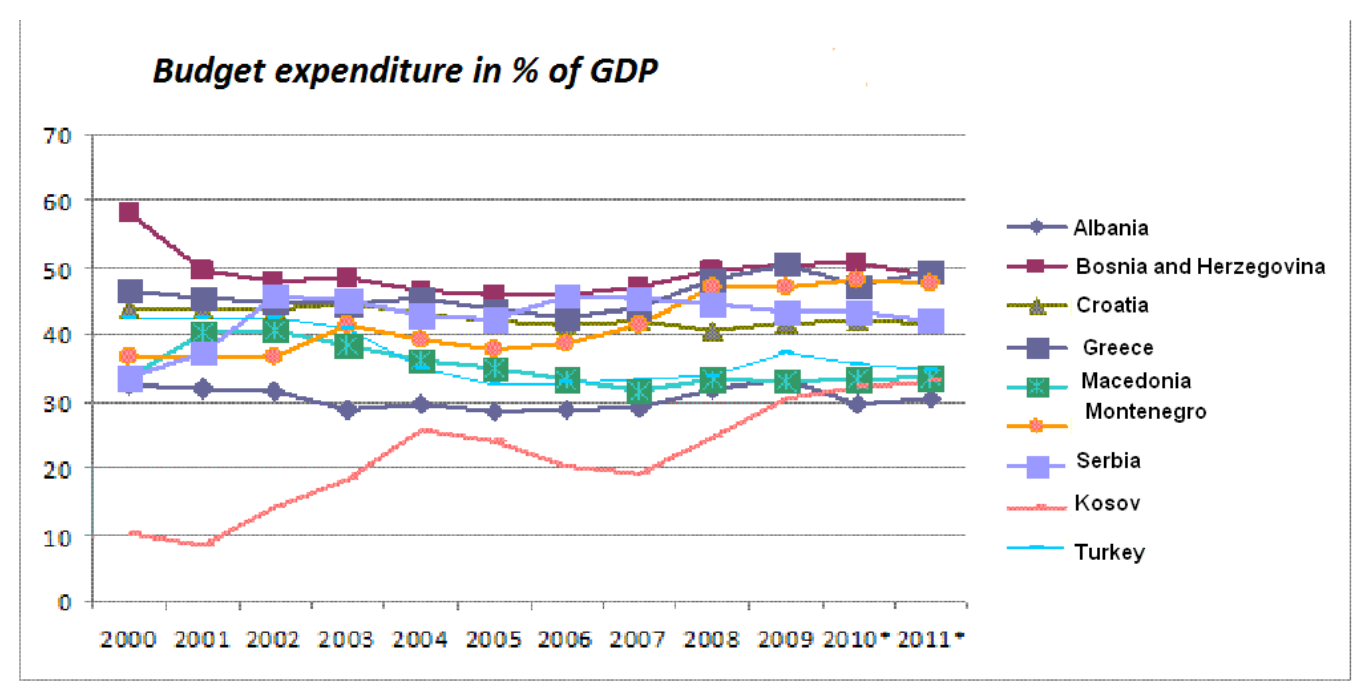

The country with the greatest budget expenditure reduction of over the last decade is Bosnia and Herzegovina, while the country with the largest increase is Kosovo. 


\section{Public Expenditure by Functional Classification}

In order to analyze the expenditures by function we are using indicators that reflect the expenses in relation to GDP and in absolute form. As it can be seen from the "Map", in 2012, the function of "Social security and Social Insurance" continues to absorb most of the Albanians money. The amount allocated was 105.7 billion, in other words, $26.01 \%$ of the entire budget. Compared to 2010, this feature has been increased by $7 \%$. In the second place, but with a significant difference is the use of "Transport" with 48.8 billion or $11.16 \%$ of the budget. Compared with a year ago this feature has been increased very slightly, with about 500 million.

Figure 26: State Budget 2013 according to the Functions Source: Ministry of Finance, 2014

\section{State Budget 2013 Allocation}

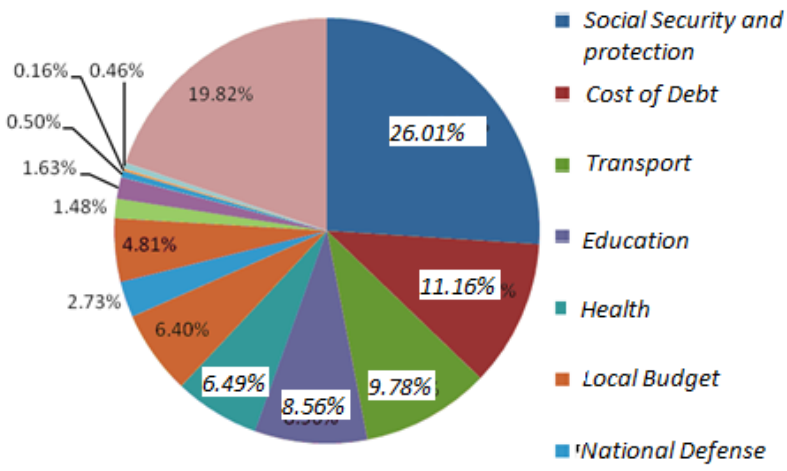

The third function funded by the states budget, is "Debt". The amounts paid for the interest of the domestic and external debt for 2011 is 47.8 billion. It means that Albanians are paying more interest than investment in roads, or the education system, health and so on. This item absorbs $11.7 \%$ of total expenditures and has been steadily increasing since 2007, with five milliards each year. "Education" and "Health" remain constant by about $10 \%$ and $8-9 \%$ of the budget, while the "Defense" level is $5.2 \%$, deepening further the gap with "Order and Security". That means more money for the national security than for the internal order and the police. Despite the advertisement of Agriculture as a high priority to the development of the country, its budget does not exceed $2 \%$ of the State's Budget. "Culture" is positioned worse, and it also includes Tourism within. Only 3.4 billion or $0.83 \%$ of the budget is allocated to Cultural Heritage, Museums, Forts that are demolished or archaeological parks of Albania. This amount is included within the budget for tourism development, which is at $0.06 \%$ of the total budget.

\section{Comparison with OECD countries}

All OECD member countries consume most of the budget for social security, with the exception of South Korea and the United States. South Korea spends most of its budget on economic issues and U. S. on healthcare. Both countries spend less on social security compared to other OECD ${ }^{1}$ countries. Health expenses are the second priority leading after social security among member countries of the OECD. A well-organized health system helps increase the efficiency and productivity. This is an area where inefficiencies cause significant cost for economy. Expenditure on health, in percentage of the total budget is among the three main priorities for all countries, with the exception of Hungary in which it is ranked the fifth. In Korea, Netherlands, Poland and Sweden these expenditures are ranked the fourth. Ireland and U. S. pay 21 percent of their budget on health, while Japan and Iceland $19 \%$. 
Poland lies at the other extreme, spending only $10 \%$ of the budget on health. Hungary, Greece and the Netherlands spend 11 percent. Education is the third and among the foremost priorities of the OECD countries. Long-term investments in education and human capital play an important role in maximizing productivity.

Healthy economies tend to invest a large share of GDP in building human capital. Investment in education and training contribute to further growth and innovation. Education is one of the five priorities for every country, but in Denmark, Iceland , South Korea and New Zealand it is ranked in second place and it is ranked in the third for Ireland, Luxembourg, Netherlands, Norway, Portugal, Sweden, UK and USA, and in the fourth and fifth place for other countries. Iceland and New Zealand allocate 19 percent of the budget on education, more than any other country, Canada 18 percent, South Korea and the U. S. 17 percent of the budget. Greece stands at the lowest level with only 7 percent of the budget allocated to education, Germany 9 percent, Italy 10 percent, and eight other countries about 11 percent.

\section{Expenditure on the functioning of Social Security and Social Defense/Protection}

Expenditures on social protection for families with low income and unemployment payments are funds which express the re-allocation of the state budget. Transfers to the Special Fund of Social Insurance of the State Budget are calculated as the difference between income from social security and social insurance expenditures. A large part of this amount is used to cover the deficit in the social insurance scheme, which itself suffers from insufficiency of contributions collected to cover pensions distribution. For this reason, social insurance subsidy is becoming a constant problem. Also, through transfers from the budget to the SHI (Social and Health Insurance), the state realizes a part of its policy for additional payments to certain individuals, which are outside the insurance scheme.

Figure 3: State Budget Transfers for SHI, Source: Ministry of Finance, 2014

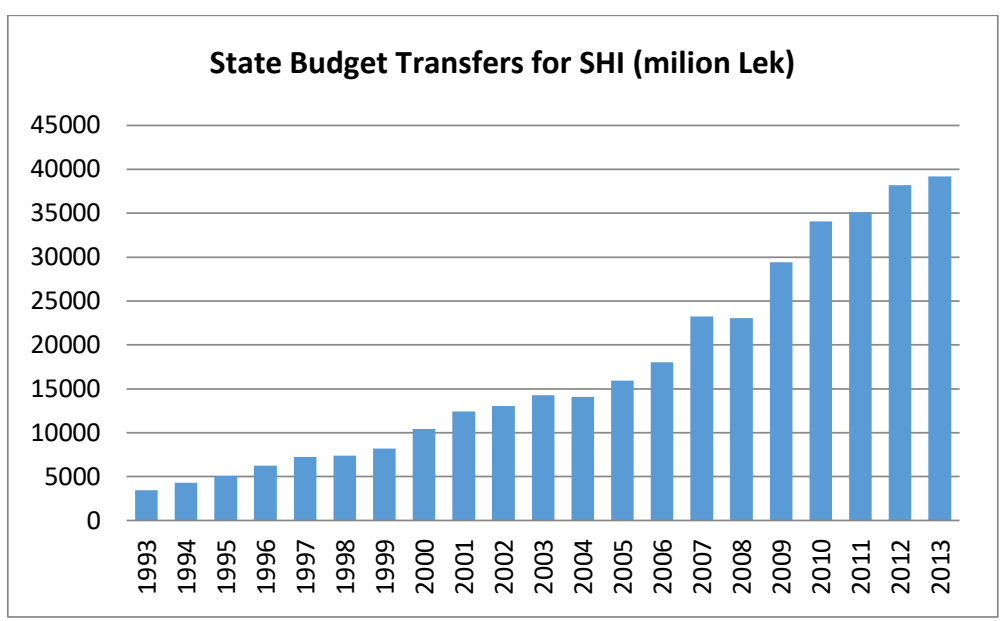

\section{Expenses for Transport and Public Affairs}

Transport and communication are key factors to the economic development of a country. In the market economy conditions, transportation and communication are essential elements that have an impact on reducing the costs of the economic transactions and in the sustainable development of the country, especially in the development of rural suburban areas of a country. In Albania, the need to support this sector during the transition period has been a necessity because of the fairly low level and backwardness Albania inherited in the field of transport and communications in general. The distribution of the budget in percentage for the function of "Transport and Public Affairs" for 2013 is as follows

Figure 4: Distribution of the budget in Percentage for the "Transport and Public Affairs" Function 2013, Source: Ministry of Finance, 2014 


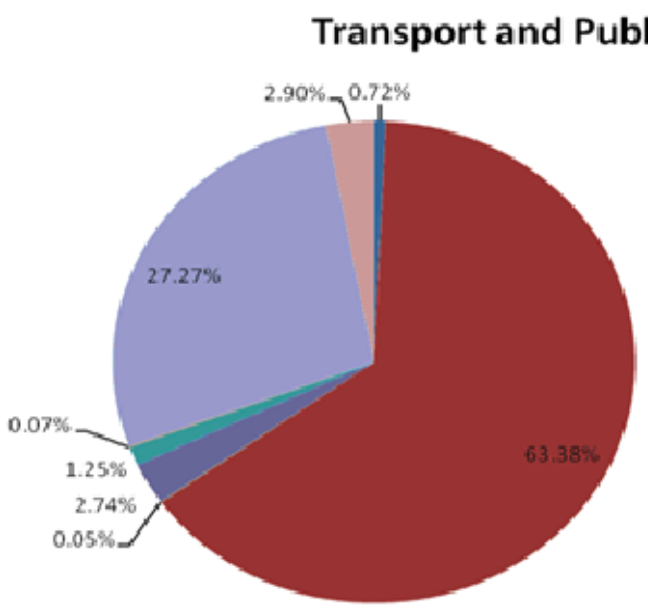

\author{
- :Planning \& \\ Management \\ - Road Transport \\ = Support for studies in \\ transport \\ 'Marine Transportation \\ "inailways \\ - Air Transport \\ $=$ Water supply and sewerage \\ =. Jrban planning
}

As it can be seen from the table, most of the budget for "Transport and Public Affairs" is allocated to the national road network ( $65.68 \%$ of the 2013 Budget). Among the major investments that have been made in this direction in the recent years are the following:

- Construction of Rreshen-Kalimash road $60 \mathrm{~km}$, with four lanes and a tunnel about $6 \mathrm{~km}$, which cost around 520 million Euros, or $50 \%$ of the Albanian Government funding. The rest was funded by commercial loans. (finished in 2009)

- Construction of Milot-Rreshen road, $26 \mathrm{~km}$, (part of the corridor Durresi - Kukesi- Morina), funded from the World Bank \& F. OPEC (USD 35 million) and the Government of Albania (finished in 2009)

- The construction of the Fier- Levan - Vlore road, $43 \mathrm{~km}$, about 101 million euros (finished in 2010).

- The construction of Fier- Levan -Tepelena road, 71 km, (about 70 million), (finished in 2010).

- Build parallel secondary roads in Rrogozhina-Lushnja- Fieri interval, 2. 8 billion (year . 2009 - 2012)

The second priority of this function is the construction and maintenance of Water Supply and Sewerage. This has absorbed about 23. 8 percent of the 2013 budget. The water supply and sanitation sector is characterized by a poor management and its decentralization has not given the expected improvements. Incomes have been rising from year to year, but the subsidy continues to be necessary to keep it functioning, at a time when the sector could have been profitable.

Income of Water Supply and Sewerage Sector (WSSS) in 2010, has experienced a high increase, with about $50 \%$ more than in 2009. The amount of subsidy in 2010 was 1.8 times higher than the previous year. If we examine the subsidy I income ratio a decrease would be noticed, by $40 \%$ in 2008 to $22 \%$ in 2009 , but again 2010 is accompanied by a further increase, taking the ratio to $42 \%$.

\title{
5. Conclusions and Recommendations
}

Albania has the lowest expenditures to GDP in the region. Meanwhile ranked in first place is: Greece (50.4\%) followed by Bosnia and Herzegovina (50\%), Montenegro (47 \%), Serbia (44\%), Croatia (42\%), Turkey (37\%), Macedonia (33\%) and Kosovo (31\%). The analysis of public expenses for public functions showed that the priorities of our country have been different compared to OECD countries. All OECD member countries spent most of the budget for social security, except of South Korea and the United States. Health expenses are the second priority leading after social security among the member countries of the OECD. Expenditures on health, as a percentage of the total budget are the third main priority for all countries, except for Hungary (fifth place), and Korea, Netherlands, Poland and Sweden (fourth). Ireland and U. S. devote 21 percent of total expenditures in health while Japan and Iceland $19 \%$. Poland lies at the other extreme, spending only $10 \%$ on health expenditure, while Hungary, Greece and the Netherlands spend 11 percent. "Transport and Public Affairs" 
are ranked the second, with about $10.64 \%$ of budget funds in 2013. Compared to 2012 , this function has decreased by 7 . $8 \%$. Meanwhile, "Education" and "Health " remain respectively at the levels of $8.96 \%$ and $9.8 \%$, approximately the same as in the previous years. Education is the third among the foremost priority for OECD countries. Countries with healthy economies tend to invest a huge weight of GDP in building human capital. Education is one of the five priorities for every country. Denmark, Iceland, South Korea and New Zealand ranked education in second place, and Ireland, Luxembourg, Netherlands, Norway, Portugal, Swede, UK and USA inthe third place. Greece stands at a low level in this direction with only 7 percent of the allocated budget, Germany 9 percent, Italy 10 percent, and eight other countries about 11 percent.

One of the most emergent needs that are recommended in this paper is to improve the quality of education in order for the system to be similar and approximate to the EU standards. Albania is more in need for a skilled workforce, equipped with the competencies, knowledge and skills to hand the work, which cannot be won only with the primary education system. Persistent gaps in the educational outcomes of secondary and higher education would constitute a limiting factor for the future economic prospects of the country. Organic Budget Law was a necessity to reflect changes made to the operation and the separation of powers, as well as the design and implementation of the budget. Public Investment Management is an important element of expenditure reform. The planning funds for investments suffers from two problems : the fragmentation of funds in many objects, as well as the investment for many years in the same object without a clear idea of the cost of this investment. Often these funds are used for purposes other than those for which the funds were created, or are created to hide the transactions from submission to parliament or the public becoming a source of corruption.

\section{References}

[1] Afonso, António, St Aubyn, and Vito Tanzi (2005), "Public sector efficiency: An international comparison", Public Choice, forthcoming. https://www. repository. utl. pt/bitstream/10400. 5/2131/1/ecbwp581. pdf

[2] Alfonso Arpaia (2010) Expenditure and Economic Groëth in the EU, long - run tendencies and short - term adjustment and Nicola Curci http://ec. europa. eu/economy finance/publications/economic paper/2010/pdf/ecp405 summary en. pdf

[3] Alfonso ARPAIA, Alessandro TURRINI (February 2008): Government Expenditure and Economic Groeth in the EU, long - run tendencies and short - term adjustment http://ciep. itam. mx/ rahul. giri/uploads/1/1/3/6/113608/accntngforcrosscntryincdiff_caselli_ch9handbkofecongrwth2005. pdf

[4] Clements B. , Boldacci E. and Mulas-Granados C., (April 2002), Expenditure Composition, Fiscal Adjustment, and Growth in Low Income Countries http://www. imf. org/external/pubs/ft/wp/2002/wp0277. pdf

[5] Clements B. , Gupta S. , Karpowicz I. and Tareq Sh. (September 2010), Evaluating Government Employment and Compensation http://www. imf. org/external/pubs/ft/tnm/2010/tnm1015. pdf

[6] Clements, Benedict, 1999, "The Efficiency of Education Expenditure in Portugal, "IMF Working Paper 99/179.

[7] CRD (group work: Albert Gajo, Mirlinda Russia, Rosie Beqiri , 2003) : Analysis of Public Expenditure in Years http://www. qkzh. org/publications/PubExpenditEn. pdf

[8] Curristine, T. (2009), "Performance Budgeting (PB) in OECD Countries", OECD Presentation at the Performance budgeting and the quality of public spending Conference, Ministero dell'Economia e delle Finanze -Ragioneria Generale dello Stato Rome, Italy

[9] De Borger, Bruno, and Kristian Kerstens (1996), "Cost efficiency of Belgian local governments: A comparative analysis of FDH, DEA, and econometric approaches", Regional Science and Urban Economics 26: 145-170.

[10] DeEa Sabina and Michael ETTLINGER (October 2009): Comparing Public Spending and Priorities across OECD Countries http://sticerd. Ise. ac. uk/dps/case/cr/CASEreport58. pdf

[11] Dhori Kule - Dieter H. Ëenzel (September 2003) Dimensions of Public Sector, Paper presented at the Fourth Conference of the Bank of Albania http://www. bankofalbania. org/web/pub/kule_wenzel_244_1. pdf

[12] Division for Public Administration and Development, (January, 2007): Public Administration and Democratic Governance, Governments Serving Citizens.

[13] EUROPEAN COMMISION, Occasional Papers 125, (Dec, 2012). The Quality of Public Expenditures in the EU http://ec. europa. eu/economy_finance/publications/occasional_paper/2012/pdf/ocp125_en. pdf

[14] Francesco Grigoli (2012) Public Expenditure in the Slovak Republic, Composition and Technical Efficiency https://www. imf. org/external/pubs/ft/wp/2012/wp12173. pdf

[15] International Monetary Fund (January 2013): IMF Country Report No. 13/7 Albania, Article IV Consultation http://www. imf. org/external/country/alb/index. htm?type=9998\#56 
[16] Prof. Dhori Dr. Kule, Olta Milov (2008) : Public Sector Performance and Its Impact on Economic Growth http://www. doktoratura. unitir. edu. al/wp-content/uploads/2013/03/Doktoratura-Olta-Milova-Fakulteti-EkonomiseDepartamenti-i-Ekonomiksit. pdf

[17] Report of the High Level Expert Committee (July 2011): Efficient Management of Public Expenditure http://planningcommission. nic. in/reports/genrep/rep hle. pdf

[18] Shengeen Neetha Fan and Rao (2008) Public Spending In Developing Countries: Trends, Determination, and Impact EPTD DISCUSSION PAPER NO. 99 http://siteresources. worldbank. org/EXTRESPUBEXPANAAGR/Resources/ifpri2. pdf

[19] Sopek Petar (2011): Testing the Sustainability of the Croatian public debt dynamic models http://www. google.

com/url?sa=t\&rct=j\&q=\&esrc=s\&source=web\&cd=1\&ved=0CCsQFjAA\&url=http\%3A\%2F\%2Fhrcak. srce. hr\%2Ffile\%2F116484\&ei=P2tXU6OdJ8m5yAPHxoFo\&usg=AFQjCNFrNPGluS6R25J4TX8sIBOHNFuPQ\&sig2=ZPZXXZkQEnF4ad4zVZkQrA

[20] Verhoeven, Marijn ; Gunnarsson, Victoria ; Carcillo, Stéphane, (November 2007), Education and Health in G7 Countries: Achieving Better Outcomes with Less Spending

[21] World Bank (2008): Albania - Public Expenditure and Financial Accountability (PEFA) Public Financial Management Assessment http://ec. europa. eu/enlargement/pdf/financial_assistance/ipa/2010/pf_2_public_financial_management_en.pdf 